\title{
Twice-Over Rotational Grazing and Its Impacts on Grassland Songbird Abundance and Habitat Structure
}

\author{
Cristina L. Ranellucci, ${ }^{1}$ Nicola Koper, ${ }^{2}$ and Darcy C. Henderson ${ }^{3}$
}

Authors are ${ }^{1}$ Ecology Consultant, Population Conservation, Canadian Wildlife Service, Environment Canada, Ottawa, ON K1V 1C7, Canada;

${ }^{2}$ Associate Professor, Natural Resources Institute, University of Manitoba, Winnipeg, MB R3T 2M6, Canada; and ${ }^{3}$ Protected Areas Ecologist, Canadian Wildlife Service, Environmental Stewardship Branch, Prairie and Norther Region, Environment Canada, Saskatoon, SK S7N 0X4, Canada.

\begin{abstract}
The majority of native prairie has been lost throughout North America. Much of the remaining prairie is used for livestock grazing, so conservation of prairie species depends on sustainable grazing practices. Our objective was to evaluate the benefits of twice-over rotational grazing, in comparison with continuous season-long grazing and ungrazed "idle" fields, in conserving prairie songbirds. Northern mixed-grass prairie in southwest Manitoba, Canada is near the northern range limits for many endangered grassland birds, and thus is an important area for evaluating the contribution of twice-over grazing in the conservation of songbirds, including species at risk. In 2008 and 2009, we compared the relative abundances and diversity of grassland birds on 22 twice-over rotation, 15 season-long, and 8 ungrazed sites, using multiple 100-m fixed-radius point-count plots per site. Analyses were conducted using generalized linear mixed models. Although one obligate grassland bird, Savannah sparrows (Passerculus sandwichensis), had significantly higher relative abundances on twice-over than season-long sites in 2009, season-long pastures had higher species richness and diversity of obligate grassland birds in both years. Season-long grazing may actually benefit grassland bird communities by creating spatially heterogeneous but temporally stable areas of high and low livestock use within the pasture, thus increasing diversity of microhabitats. We found little evidence that twice-over grazing contributed to the conservation of grassland songbirds in subhumid northern mixed-grass prairies.
\end{abstract}

\section{Resumen}

La mayoría de los pastizales nativos de Norteamérica se han perdido. Sin embargo, la mayor parte del resto de los pastizales se utiliza para el pastoreo del ganado, así que la conservación de las especies del pastizal depende de prácticas de pastoreo sostenibles. Nuestros objetivos fueron evaluar los beneficios del sistema de pastoreo de rotación doble, en comparación con el pastoreo continuo estacional y no pastoreo en potreros en descanso en la conservación de aves canoras. La parte norte de los pastizales mixtos en el suroeste de Manitoba, Canadá se localiza cerca del rango de los límites de muchas especies de aves canoras de pastizales en peligro de extinción. Por tal razón es una área muy importante para evaluar la contribución del sistema de pastoreo de rotación doble en la conservación de aves de canoras, incluyendo especies en peligro. En 2008 y 2009, comparamos le relativa abundancia y diversidad de las aves de los pastizales en 22 sitios con doble rotación, 15 sitios de pastoreo continuo-estacional y 8 sitios sin pastoreo, usando múltiples puntos de $100 \mathrm{~m}$ de radio fijo, por parcela por sitio. Los análisis se realizaron usando modelos mixtos lineales generalizados. Aunque una especie obligada del pastizal, Savannah sparrows (Passerculus sandwichensis), tuvo una abundancia relativa significativamente mayor en sitios de doble rotación que en los sitios de continuo estacional en el 2009, los pastizales en el continuo estacional presentaron una mayor riqueza de especies y diversidad de aves obligadas de pastizales en ambos años. El pastoreo estacional de periodo largo, puede de hecho beneficiar a las comunidades de aves de pastizales mediante la creación de espacios con áreas heterogéneas pero temporalmente estables con alto y bajo índice de uso por el ganado dentro del pastizal. Produciendo en consecuencia, un incremento en la diversidad de micro-hábitats. Encontramos poca evidencia que el sistema de pastoreo de doble rotación contribuye a la conservación de aves canoras en los pastizales mixtos sub-húmedos del Norte.

Key Words: obligate grassland birds, rangeland management, season-long grazing, stocking rates

\section{INTRODUCTION}

Research was funded by Manitoba Conservation through the Sustainable Development Innovations Fund (SDIF) and the Alice Chambers Hyacinth Colomb Assistantship Program, the Manitoba Habitat Heritage Corporation, the Manitoba Mixed-grass Prairie Habitat Stewardship Program and Environment Canada, and the Natural Sciences and Engineering Research Council of Canada (NSERC).

At the time of research, Ranelluci was a master's student in Natural Resource Management, Natural Resources Institute, University of Manitoba, Winnipeg, MB R3T 2N2, Canada.

Correspondence: Dr Nicola Koper, Associate Professor, Natural Resources Institute, University of Manitoba, 305 Sinnott Bldg, 70 Dysart Rd, Winnipeg, MB R3T 2N2, Canada. Email: koper@cc.umanitoba.ca

Manuscript received 24 March 2011; manuscript accepted 24 October 2011.
North American prairies have experienced vast reductions in their area relative to historical extents (Samson and Knopf 1994). Perhaps in response to this loss of habitat, grassland birds have experienced greater declines in population sizes than any other group of North American birds during the past 25 years (Peterjohn and Sauer 1993; Knopf 1994; Askins et al. 2007). Historical ecological drivers that maintained North American mixed-grass prairies were drought, grazing, and fire, all of which played a significant role in the evolution of grassland species (Knopf and Samson 1997; Askins et al. 2007). Without these periodic but frequent events, woody vegetation 
can invade and become established in many relatively mesic grassland areas, including the mixed-grass prairie region of southwestern Manitoba. Presently, grazing by cattle is the primary use of fragments of grassland that remain throughout the northern Great Plains. The removal of native grazers and the introduction of domestic livestock grazing systems have significantly altered grazing pressures and may have contributed to declines in grassland bird populations (Samson et al. 2004). However, some range management practices in remaining prairie fragments may help buffer these declines in grassland bird breeding habitat (Herkert 1994; Johnson and Igl 2001).

The main factors that distinguish grazing systems are stocking rates, the timing of grazing, and livestock distribution (Holechek et al. 1998). Typically, season-long and rotational grazing systems differ in stocking rates and in the temporal and spatial manipulation of grazing (Savory 1988). Rotational grazing systems were originally introduced to improve rangeland conditions (Heady 1961; Holechek et al. 1998), and in many ranching cultures rotational grazing is still believed to be a superior way to manage resources. However, relatively few empirical studies actually support the hypothesis that rotational grazing systems are superior to other management regimes (Hart et al. 1993; Manley et al. 1997; Briske et al. 2008). Given the controversy surrounding the benefits of grazing regimes, it is important to evaluate the effects of both continuous season-long and rotational grazing systems to provide specific recommendations for the management of prairies within the northern Great Plains.

Twice-over rotation grazing is widely promoted in the subhumid to humid northeastern Great Plains, which receives on average $300-550 \mathrm{~mm}$ of precipitation annually (Shepherd and McGinn 2003). Twice-over grazing is a practical application of the grazing optimization hypothesis (McNaughton 1979). It aims to increase productivity and thus forage availability of native grasses by defoliating plants at particular phenological stages. In theory, twice-over rotation systems apply a single defoliation of a grass plant between the three-leaf stage and reproductive culm elongation, or boot-stage, to stimulate vegetative tillering and delay or reduce reproductive culm development for the remainder of the season (Milchunas et al. 1988). Suppressing reproductive culm development maintains protein content in vegetative tillers. If those plants are then given rest, it is hypothesized that the new tillers will increase grass plant density, reduce bare ground exposed to potential erosion, and provide greater aboveground production of grass biomass (McNaughton 1979) for a second defoliation by grazing animals later in the season. In part because of the increased aboveground net primary productivity, and because of the maintained protein content in vegetative tillers, twice-over rotation is theorized to ultimately allow greater stocking rates and economic returns (Biondini and Manske 1996). Prairie composed of both C3 and C4 plants could ideally be grazed first to stimulate tillering of C3 grasses, then during the second grazing period livestock would prefer the early growth of C4 grasses, followed by the later growth of $\mathrm{C} 3$ grasses, followed by the later growth of $\mathrm{C} 4$ grasses.

In the northeastern Great Plains, most C3 grasses will not reach the boot-stage until the middle of June, which is also when many C4 grass tillers have reached the three-leaf stage. Thus, a twice-over rotation system in this region divides pastures into three to six paddocks and each paddock is grazed twice over a 4-mo to 5-mo season between June and midOctober, or as early as May on a spring pasture. During the first grazing period (June to mid-July), cattle are rotated among paddocks approximately every $2 \mathrm{wk}$, and careful phenological monitoring by managers is required to estimate the appropriate timing. The second grazing period, typically from mid-July to mid-October, may be drawn out for a few weeks or up to a month per paddock, depending on the amount of increased aboveground net primary productivity. The twice-over rotation system is promoted by several government, university, and notfor-profit conservation agencies in Canada and the United States; this includes the provision of financial incentives and in-kind support to encourage producers to adopt this grazing system. For grassland birds, the assumption is that any grazing system that provides a period of rest from grazing during the critical nesting period might be beneficial to bird populations relative to continuous season-long grazing (Wilson and Belcher 1989; Sutter 1997). Conversely, populations of orthoptera (grasshoppers), a primary component of grassland songbird diets (Wiens and Rotenberry 1981), might be lower on twiceover compared with season-long pastures (Onsager 2000), which might result in grassland songbirds selecting other sites with more abundant prey resources. Also, season-long grazing might lead to less uniform use of pastures and thus a more heterogeneous vegetation structure (Coughenour 1991; Holechek et al. 1998), which may increase the range of available niches and therefore species diversity compared with rotational grazing systems (Knopf 1996; Askins et al. 2007).

Enticing as the theoretical rationale for twice-over grazing may be, many studies have failed to detect benefits of rotational grazing on aboveground biomass or plant species composition when compared to season-long grazing (Buckness et al. 2001; Briske et al. 2008). The grazing optimization hypothesis was developed based on ecological observations from the Serengeti (McNaughton 1979); its predictions have not been supported by empirical studies conducted in the northern Great Plains of North America (Biondini and Manske 1996). Very little research has addressed the effectiveness of twice-over rotational grazing on vegetation or bird populations; one study evaluated effects of twice-over grazing on chestnut-collared longspur (Calcarius ornatus) densities (Messmer 1990). The contrast between our study and Messmer's (1990) may be that we detected no significant difference in habitat structure due to litter depth, vegetation height, or vertical density between sites grazed season-long or twice-over rotationally.

To address our knowledge gaps and help evaluate the efficacy of promoting twice-over grazing as a conservation tool for grassland songbirds, we compared the diversity and densities of grassland birds on twice-over rotationally grazed pastures, season-long grazed pastures, and ungrazed "idle" fields at multiple independent sites across a large study area. Our specific objectives were to 1) compare the diversity and densities of grassland birds present on sites of each treatment; 2) determine the effects of grazing management on vegetation structure; and to 3) determine the extent to which twice-over grazed pastures provide habitat for species of conservation concern.

Relevant ecological theories lead to divergent predictions regarding potential effects of twice-over grazing on grassland songbirds. Twice-over grazing rotations might lead to higher songbird abundances if rest periods increase potential nesting 


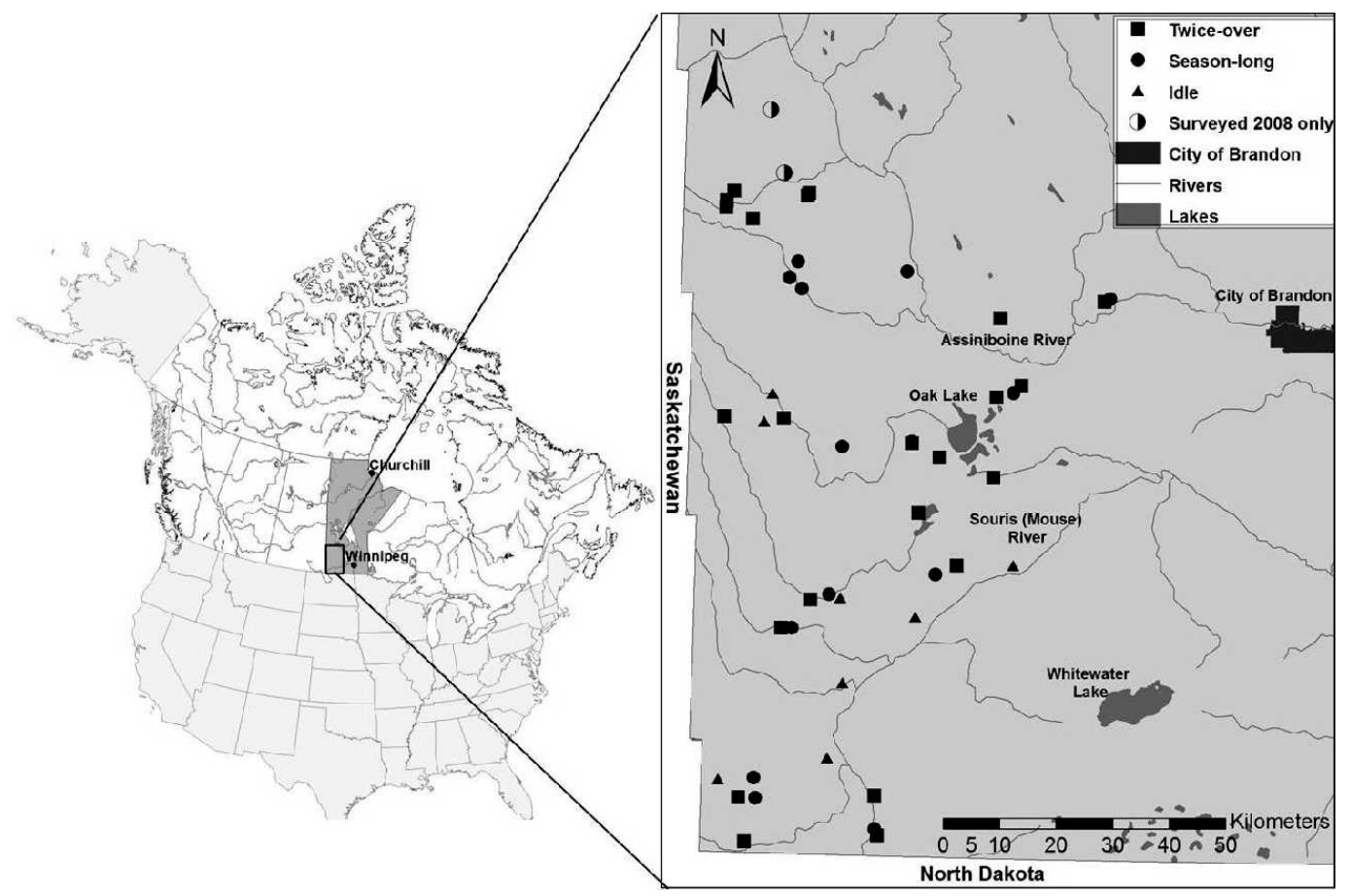

Figure 1. Study site locations in southwest Manitoba, Canada, in 2008 and 2009, identified by treatment.

success. Alternatively, season-long grazing might increase songbird abundances if prey resources are more abundant, or if season-long grazing results in a more heterogeneous vegetation structure than twice-over grazing. Monitoring invertebrate abundance and nesting success were beyond the scope of our research; for this study, we restricted our empirical data collection to vegetation structure, and grassland songbird relative abundance and diversity.

\section{MATERIALS AND METHODS}

The study area was located within the Aspen Parkland Ecoregion of southwest Manitoba, Canada, extending from the Saskatchewan and North Dakota borders (lat $49^{\circ} 02^{\prime} 81.78^{\prime \prime} \mathrm{N}$, long $101^{\circ} 25^{\prime} 74.17^{\prime \prime} \mathrm{W}$ ), to approximately $145 \mathrm{~km}$ north (lat $50^{\circ} 17^{\prime} 74.57^{\prime \prime} \mathrm{N}$, long $\left.101^{\circ} 23^{\prime} 91.46^{\prime \prime} \mathrm{W}\right)$, and about $106 \mathrm{~km}$ east (lat $49^{\circ} 89^{\prime} 96.54^{\prime \prime} \mathrm{N}$, long $100^{\circ} 40^{\prime} 76.44^{\prime \prime} \mathrm{W}$; Fig. 1). The regional landscape is primarily cultivated for annual crops, with few remaining native rangelands on river valley slopes, seasonally flooded lowlands, and sand dune complexes. Remaining native rangelands are a mosaic of upland grasslands, forest patches dominated by trembling aspen (Populus tremuloides Mich.), and lowland freshwater wetlands. Native grasses most common in the study area included C3 grasses such as wheatgrass (Elymus trachycaulus [Link] Gould ex. Shrinners; E. lanceolatus (Scribn. \& J.G.Sm.) Gould; Pascopyrum smithii [Rydb.] A. Löve), spear grasses (Hesperostipa comata [Trin. \& Rupr.] Barkworth; Hesperostipa spartea [Trin.] Barkworth; Hesperostipa curtiseta [Hitchc.] Barkworth), and June grass (Koeleria macrantha [Ledeb.] Schult.); and C4 grasses such as bluestems (Andropogon gerardii Vitman; Schizachyrium scoparium [Michx.] Nash) and blue grama (Bouteloua gracilis [Willd. ex Kunth] Lag. ex Griffiths). Several sedges (Carex spp. L.) are also present.
Rangelands in this fragmented ecoregion include patches of long-abandoned cultivated fields seeded to, or invaded to some degree by, one or more nonnative grass species including C3 grasses crested wheatgrass (Agropyron cristatum L. Gaertn.), quack grass (Elymus repens L. Gould), smooth brome (Bromus inermis Leyss.), and Kentucky bluegrass (Poa pratensis L.). Leafy spurge (Euphoria esula L.) was also a common nonnative forb species across the study area, while the most common native shrubs were western snowberry (Symphoricarpos occidentalis Hook.) and wolf willow (Elaeagnus commutata Bernh. ex Rydb.).

\section{Grazing Treatments}

Independent sites within the study area were pastures grazed using a twice-over system, season-long system, or were ungrazed "idle" fields. Sites ranged from 65 ha to 260 ha. Approximately half of the twice-over sites surveyed had been following the twice-over rotation system for 2-4 yr $(56.5 \%$, SD 0.83), while the other half had been grazed twice-over rotationally for $5-7$ yr $(43.5 \%$, SD 0.92$)$. Limited availability of idle sites, and limited access to appropriate season-long sites, prevented us from surveying equal sample sizes among grazing treatments, resulting in a total of 22 twice-over sites, 15 season-long sites, and eight idle sites. Producers rotated cattle in three to six paddocks in the twice-over system, whereas pastures grazed season-long were not divided into paddocks. Season-long pastures held cattle from May to the end of October. In the twice-over program, cattle were pastured between 1 June and 15 October of each year (Manitoba Habitat Heritage Corporation [MHHC] 2002). Grazing dates were similar for both grazing regimes; all twiceover pastures, and six of the season-long pastures, introduced cattle 1 June of both years. The initial grazing dates for the 


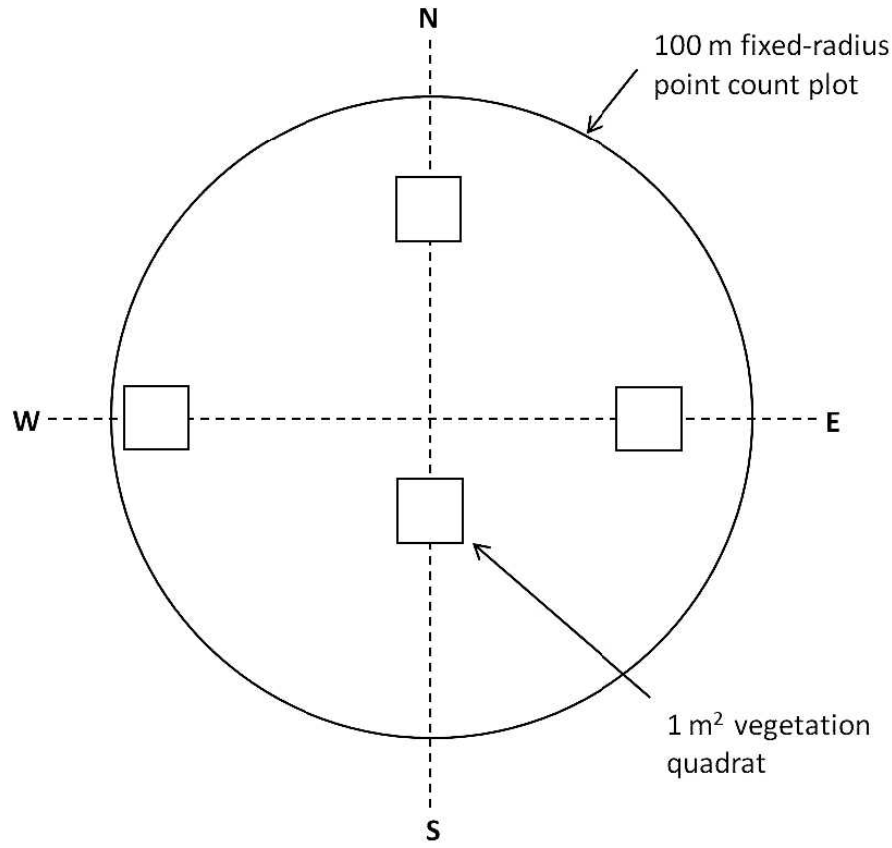

Figure 2. Locations of the four vegetation quadrats within the pointcount plot, each along a cardinal direction and at a random distance from the center of the plot, in southwest Manitoba, Canada.

remaining season-long pastures are unknown. For a pasture to qualify for a twice-over agreement with the MHHC, which provides landowners with funding for infrastructure development (e.g., fencing), it must contain a minimum of $30 \%$ native vegetation. Because the amount of native and nonnative vegetation may influence bird abundances (Davis and Duncan 1999), we also selected only season-long pastures containing at least $30 \%$ native vegetation for comparison. Idle fields in our study were defined as native rangelands excluded from livestock grazing, mowing, burning, or cultivation for at least $5 \mathrm{yr}$ prior to initiation of the study.

\section{Grassland Bird Surveys}

The relative abundances of grassland birds were measured in 2008 and 2009 using four different observers, at four to eight randomly placed, $6-\mathrm{min}$ duration, $100-\mathrm{m}$ radius point-count plots per site. Two rounds of point-counts were conducted from sunrise to $1000 \mathrm{~h}$ between May and June of both years (Koper and Schmiegelow 2006a). Surveys were not conducted during rain and wind $\geq 16 \mathrm{~km} \cdot \mathrm{h}^{-1}$ (Robbins 1981). We chose to control for observer bias and avian detectability in the field rather than using posthoc statistical adjustments, by rotating observers among rounds within plots, and plots within treatments for a number of reasons. First, detectability of grassland birds in open habitats is higher than in dense habitats (Reynolds et al. 1980); however, estimates of distance to detected but unseen birds in grasslands are often coarse or inaccurate (Koper, unpublished data, 2008). Second, grassland songbird distributions do not meet assumptions of declining detectability with distance to observer, precluding the use of distance sampling (Fisher, Giovanni, Davis, and Koper, unpublished data, 2010). Finally, existing statistical methods do not allow for accurate correction of bias in point-count surveys under normal field conditions (Johnson 2008; Efford and Dawson 2009). Because difficulties with converting avian detections to avian densities are insurmountable with existing methods (Efford and Dawson 2009), we treat observations as relative abundances and do not claim that our data represent avian densities.

\section{Vegetation Surveys}

Vegetation surveys were conducted between 22 May 2008 and 14 June 2008, and 20 May 2009 and 5 June 2009, which is when most species of grassland songbirds select and establish breeding territories (Wiens 1969). We focused on vegetation structure since birds are more likely to use cues such as vegetation cover and structure for habitat selection rather than select for native versus nonnative vegetation (Davis and Duncan 1999; Madden et al. 2000). Vegetation habitat structure for grassland birds was recorded at four quadrats in each point-count plot, one along each cardinal direction from the center of the plot but at a randomly selected distance along the 100-m radius (Fig. 2). Litter depth and vegetation height were measured using a meter stick, and visual obstruction measurements (VOM) were taken to determine vertical cover using a Robel pole (Robel et al. 1970). Visual estimates for percent cover of shrubs (all woody vegetation), forb species, litter, standing grasses (dead and alive), and bare ground within a $1 \times 1 \mathrm{~m}$ quadrat, were based on methods by Daubenmire (1959). For this study, dead plant material lying on the ground was considered litter (Facelli and Pickett 1991). Measurements were averaged among the four vegetation plots to obtain a single value per point-count plot.

\section{Statistical Analysis}

To compare effects of grazing systems on species with different life-history strategies, we categorized songbirds into three groups according to the classification of grassland birds proposed by Vickery et al. (1999): obligate grassland birds, facultative grassland birds, and nongrassland birds (Table 1; also see Ranellucci 2010 for a complete list of bird species). Obligate grassland birds require grassland habitat to carry out at least part of their life history, whereas facultative grassland birds are not dependent on grasslands for their life histories but use them regularly. Any bird that did not fall into one of these two categories was classified as a nongrassland bird. Individual species of conservation concern were examined independently, including the provincially threatened Sprague's pipit (Anthus spragueii); the nationally threatened and provincially endangered loggerhead shrike (Lanius ludovicianus); the provincially endangered Baird's sparrow (Ammodramus bairdii); and the chestnut collared-longspur, which has been recommended for listing as nationally threatened (as of November 2009; Committee on the Status of Endangered Wildlife in Canada 2009).

We used generalized linear mixed models (GLMMs) in PROC GLIMMIX of SAS version 9.2 to determine the effects of management regime and local vegetation characteristics on avian species richness, diversity, and relative abundances of individual species. GLMMs have two favourable characteristics that made them appropriate for our analyses. First, they allowed us to include a random variable (site) in the models, to statistically control for the clustering of plots within sites and thus avoid pseudoreplication. Second, GLMMs allowed us to 
Table 1. Mean and standard deviation of species richness, diversity, and relative abundance of grassland birds by treatment observed in southwest Manitoba, Canada, in 2008 and 2009.

\begin{tabular}{|c|c|c|c|c|c|c|}
\hline \multirow[b]{2}{*}{ Species } & \multicolumn{2}{|c|}{ Twice-over } & \multicolumn{2}{|c|}{ Season-Iong } & \multicolumn{2}{|c|}{ Idle } \\
\hline & 2008 & 2009 & 2008 & 2009 & 2008 & 2009 \\
\hline \multicolumn{7}{|l|}{ Obligate grassland birds } \\
\hline Species richness & $2.2 \pm 1.0$ & $2.5 \pm 1.1$ & $2.4 \pm 1.2$ & $2.8 \pm 1.2$ & $0.5 \pm 0.6$ & $1.1 \pm 1.0$ \\
\hline Total abundance & $4.3 \pm 2.4$ & $4.9 \pm 2.9$ & $4.6 \pm 2.8$ & $5.6 \pm 2.9$ & $1.0 \pm 1.4$ & $1.6 \pm 1.7$ \\
\hline Species diversity & $0.9 \pm 0.4$ & $1.2 \pm 0.5$ & $1.0 \pm 0.4$ & $1.3 \pm 0.6$ & $0.6 \pm 0.4$ & $0.6 \pm 0.5$ \\
\hline Bobolink & $0.1 \pm 0.4$ & $0.1 \pm 0.4$ & $0.4 \pm 0.9$ & $0.4 \pm 1.2$ & $0.4 \pm 0.8$ & $0.2 \pm 0.4$ \\
\hline Le Conte's sparrow & $0.2 \pm 0.5$ & $0.1 \pm 0.3$ & $0.1 \pm 0.3$ & $0.1 \pm 0.3$ & $0.0 \pm 0.2$ & $0.0 \pm 0.2$ \\
\hline Savannah sparrow & $1.6 \pm 1.2$ & $1.4 \pm 1.2$ & $1.6 \pm 1.2$ & $1.1 \pm 0.9$ & $0.2 \pm 0.4$ & $0.3 \pm 0.6$ \\
\hline Sprague's pipit & $0.3 \pm 0.5$ & $0.4 \pm 0.6$ & $0.2 \pm 0.5$ & $0.4 \pm 0.6$ & $0.0 \pm 0.0$ & $0.0 \pm 0.1$ \\
\hline Vesper sparrow & $0.2 \pm 0.5$ & $0.2 \pm 0.4$ & $0.2 \pm 0.5$ & $0.3 \pm 0.6$ & $0.1 \pm 0.4$ & $0.1 \pm 0.3$ \\
\hline Western meadowlark & $1.5 \pm 1.0$ & $1.8 \pm 1.3$ & $1.4 \pm 1.1$ & $2.0 \pm 1.3$ & $0.2 \pm 0.4$ & $0.6 \pm 0.7$ \\
\hline \multicolumn{7}{|l|}{ Facultative grassland birds } \\
\hline Species richness & $2.3 \pm 1.0$ & $2.7 \pm 1.1$ & $2.3 \pm 0.9$ & $3.0 \pm 1.1$ & $1.9 \pm 0.9$ & $2.9 \pm 1.1$ \\
\hline Total abundance & $4.9 \pm 2.9$ & $6.1 \pm 3.2$ & $5.1 \pm 2.6$ & $6.4 \pm 2.8$ & $4.9 \pm 3.0$ & $6.6 \pm 3.2$ \\
\hline Species diversity & $1.3 \pm 0.4$ & $1.3 \pm 0.4$ & $1.3 \pm 0.4$ & $1.4 \pm 0.5$ & $1.3 \pm 0.3$ & $1.4 \pm 0.5$ \\
\hline Brown-headed cowbird & $1.0 \pm 1.4$ & $0.6 \pm 1.2$ & $0.9 \pm 1.1$ & $0.4 \pm 0.8$ & $0.7 \pm 0.9$ & $1.0 \pm 1.1$ \\
\hline Clay-colored sparrow & $1.7 \pm 1.3$ & $1.8 \pm 1.5$ & $1.5 \pm 1.3$ & $1.4 \pm 1.2$ & $1.6 \pm 1.1$ & $2.5 \pm 1.2$ \\
\hline Eastern kingbird & $0.4 \pm 0.6$ & $0.4 \pm 0.6$ & $0.5 \pm 0.8$ & $0.4 \pm 0.6$ & $0.5 \pm 0.7$ & $0.5 \pm 0.6$ \\
\hline Red-winged blackbird & $1.1 \pm 1.4$ & $0.9 \pm 1.5$ & $1.5 \pm 2.0$ & $1.1 \pm 1.6$ & $1.5 \pm 2.1$ & $1.0 \pm 1.7$ \\
\hline \multicolumn{7}{|l|}{ Nongrassland birds } \\
\hline Species richness & $0.9 \pm 0.9$ & $1.2 \pm 1.1$ & $0.7 \pm 0.7$ & $0.9 \pm 0.8$ & $1.3 \pm 1.4$ & $1.9 \pm 1.0$ \\
\hline Total abundance & $2.6 \pm 15.3$ & $1.9 \pm 2.0$ & $1.1 \pm 1.2$ & $1.2 \pm 1.1$ & $2.2 \pm 2.7$ & $3.1 \pm 2.0$ \\
\hline Species diversity & $0.6 \pm 0.4$ & $0.4 \pm 0.2$ & $0.5 \pm 0.3$ & $0.4 \pm 0.2$ & $0.8 \pm 0.5$ & $0.5 \pm 0.3$ \\
\hline
\end{tabular}

use nonnormal distributions for those dependent variables where this was appropriate, making it unnecessary to transform data. To determine which distribution to apply in each GLMM analysis, preliminary analyses were conducted using generalized linear models in PROC GENMOD in SAS. Appropriate fit of the distributions was determined using Q-Q plots and the $\chi^{2}$ :df ratio. The best-fitting distributions (all within the exponential family: Gaussian [normal], Poisson, and binomial) were then used for analysis with GLMMs. Parameter estimates $(\beta)$ provide an index of the estimated change in the response variable (avian species richness, diversity and abundance, units vary by model) for each unit of change in the predictor variable (management regime and vegetation characteristics); i.e., $\beta$ provides an index of the effect size.

Local vegetation measurements and management regimes were also modeled using GLMMs. Local vegetation measurements and management regimes were modelled separately to allow us to determine their individual, but interrelated, effects on species richness, diversity, and abundances. Years were analyzed separately to determine whether effects of management and vegetation were consistent over time. Species richness was calculated as the total number of grassland bird species recorded per point-count plot (3.2 ha), sometimes defined as species density. Relative abundance was calculated as the total number of individuals of each species per pointcount plot, and the total bird abundance was the total number of individuals of all grassland bird species per plot. Measurements of heterogeneity were calculated using the ShannonWiener heterogeneity index because it is sensitive to the rare species in the community (Wiens 1992; Krebs 1999). Rare species were of interest because these include species at risk in southwestern Manitoba (Sprague's pipit, loggerhead shrike, and Baird's sparrow). Site was the random variable in the model, to allow for clustering of point-count plots within sites. We also determined effects of management on vegetation structure. An alpha value of 0.10 was set as the level of significance to reduce the risk of committing a Type II error, a serious risk in conservation and management studies (Taylor and Gerrodette 1993).

A similarity index (Sørensen's Quantitative index) was calculated using all bird species observed during surveys to evaluate whether avian species composition differed among treatments. Sørensen's Quantitative index (also known as the Czekanowski index) quantifies differences in relative abundances between groups (Bloom 1981; Wolda 1981) and indicates how the communities differ in species diversity. Sørensen's coefficients were determined between each pair-wise treatment combination (i.e., idle:continuous, idle:twice-over, and twice-over:continuous); because no statistical tests exist to compare Sørensen's coefficients (Wolda 1981), we compared each calculated value to the expected maximum values to determine the degree of similarity in species composition among treatments (Wolda 1981). The expected maximum Sørensen's coefficients represent the expected similarity values between two random samples from the same management regime and were calculated as per Wolda (1981). Since there was an unequal number of sites and point-count plots among the three treatments, and Sørensen's index is sensitive to sample 
size (Wolda 1981), we randomly selected an equal number of sites and plots from each treatment for analysis. The idle treatment had the lowest number of sites (eight) and plots (21 in 2008 and 17 in 2009) compared with season-long and twiceover sites; therefore, we randomly selected eight sites at random from both grazing regimes, each with 21 plots in 2008 and 17 plots in 2009.

\section{RESULTS}

Average stocking rates for the season-long pastures were slightly but significantly greater than twice-over pastures in both years: $0.87 \pm 0.35 \mathrm{SD}$ animal unit months (AUM) $\cdot \mathrm{acre}^{-1}$ in 2008 and $0.88 \pm 0.41 \mathrm{SD} \mathrm{AUM} \cdot \mathrm{acre}^{-1}$ in 2009 on season-long pastures and $0.77 \pm 0.34 \mathrm{AUM} \cdot \mathrm{acre}^{-1}$ in 2008 and $0.74 \pm 0.25 \mathrm{AU}$ $\mathrm{M} \cdot$ acre $^{-1}$ in 2009 on twice-over rotation pastures $(\beta=0.10 \pm 0.06 \mathrm{SD}, P<0.0001$ in 2008 and $\beta=0.142 \pm 0.06$ $\mathrm{SD}, P<0.0001$ in 2009).

A year effect was observed relative to total abundance of obligate grassland birds between the two grazing regimes; total abundance of obligate grassland birds was greater in 2009 on season-long than twice-over pastures $(P=0.063)$ but there was no effect of grazing system in $2008(P=0.276)$. No year effect was observed in species richness or diversity of grassland birds between grazing regimes (Table 2). Effects of grazing regime on proportion of litter and amount of exposed bare ground differed between years but were consistent between years for all other measures of vegetation structure (Table 3; Appendix A; available online at http://dx.doi.org/10.2111/REM-D-11-00053.s1). Species richness of obligate grassland birds was higher on season-long than twice-over sites in both years (Table 2), by approximately $0.3 \pm 0.2$ species per plot in 2008 and by $0.5 \pm 0.2$ species per plot in 2009. Twice-over sites had approximately 2.0 species of obligate grassland birds more per point-count plot than ungrazed fields in 2008 and 1.9 more species in 2009.

Savannah sparrows were the only grassland bird to show a preference for twice-over rotation over season-long pastures, and they showed this response only in 2009 (Table 2). Bobolinks (Dolichonyx oryzivorus), an obligate grassland bird, had higher abundances on season-long than twice-over sites. Two obligate grassland birds had significantly higher abundances on twice-over than idle sites in 2008, while three obligate grassland birds had higher abundances on twice-over sites than idle sites in 2009. Although the species richness, diversity, and total abundance of facultative grassland birds did not differ significantly among treatments in either year, claycolored sparrows (Spizella pallid) showed a preference for twiceover compared to season-long pastures in 2009 (Table 2). Avian community composition in each treatment differed from both other treatments (Table 4). Bird communities of both grazed treatments (twice-over and season-long) were more similar than communities in grazed and ungrazed fields (twice-over and idle; and season-long and idle).

We found vegetation structure differed among management regime in southwestern Manitoba. For instance, season-long pastures had greater vegetation vertical density (VOM), and heterogeneity (standard deviation) of vertical density, than pastures grazed rotationally (Appendix A). Standard deviation of vegetation height was higher in twice-over sites in 2008, but season-long sites in 2009 (Appendix A). Cover of grasses and forbs was higher on season-long than twice-over sites in both years (Table 3). Higher percent cover of shrubs on the idle than the grazed sites may explain why obligate grassland birds were found in lower densities on idle fields in southwest Manitoba in both years (Table 3, Appendix A). Facultative species tended to prefer shrubbier sites with taller or denser vegetation structure (Appendix B; available online at http://dx.doi.org/10.2111/ REM-D-11-00053.s1), which may explain why facultative grassland birds occurred in higher abundances on ungrazed than grazed sites in both years.

Three of the four avian species of conservation concern that occur in southwest Manitoba were observed in both 2008 and 2009, while Loggerhead shrikes were only detected in 2008. Although Sprague's pipit relative abundances were significantly lower on idle fields in 2009 when compared to grazed pastures, relative abundances were not significantly different between season-long and twice-over sites. Chestnut-collared longspurs were also observed both years but did not show a preference among grazing regimes.

\section{DISCUSSION}

Stocking rates on the season-long pastures were slightly higher than the twice-over rotation pastures in both 2008 and 2009. Since stocking rates may have a greater impact on plant productivity compared with other grazing management practices (Heitschmidt et al. 1987; Holechek et al. 1998), the difference in stocking rates may explain the small and sometimes inconsistent differences in vegetation structure, habitat suitability for, and relative abundance of grassland birds observed between the two grazing regimes. While most of our pastures have been in the twice-over program for long enough to detect effects of specialized grazing systems (Klipple and Bement 1961), it is possible that more time is needed to create and detect improvements in habitat structure for grassland birds. Nonetheless, we feel it is imperative to evaluate the contribution to conservation of twice-over grazing during the initiation of this management program in this region, to ensure that it is an efficient and effective use of conservation dollars; it is of concern that after $7 \mathrm{yr}$, we have yet to detect any evidence of conservation benefits.

Higher stocking rates on season-long pastures may explain the greater abundance of obligate grassland birds, relative to twice-over systems. In some ecosystems, high stocking rates may negatively impact grassland bird habitat (Holechek et al. 1998; Newton 1998); for example, overgrazing can remove the dead plant material (carryover) needed to protect the soil over the winter (Willms et al. 1990). However, season-long sites surveyed in southwest Manitoba had high vegetation cover, perhaps contributing to the higher species richness and diversity of obligate grassland birds found on these sites than on twiceover rotation sites. Although high stocking rates can lead to overgrazed pastures, high stocking rates are not the only cause of overgrazing (Savory 1988). Properly managed season-long grazing, with controlled stocking rates, may be more sustainable than poorly managed rotation grazing systems (Briske et al. 2008). Our results are consistent with previous studies that suggest that grazing regimes at moderate and high grazing 
Table 2. Effects of grazing management on songbird species in southwest Manitoba, Canada, in 2008 and 2009 modeled using generalized linear mixed-models. Both season-long and idle (ungrazed) sites are compared to twice-over. A negative value of $\beta$ indicates higher abundances on twiceover rotation sites, while a positive value of $\beta$ indicates higher abundances on season-long or idle sites. Significant responses are parameters with $P \leq 0.10$. The best-fitting probability distribution (Family) is shown for each variable.

\begin{tabular}{|c|c|c|c|c|c|c|c|c|c|c|c|c|c|}
\hline \multirow[b]{3}{*}{ Species } & \multirow[b]{3}{*}{ Family } & \multicolumn{6}{|c|}{ Twice-over vs. season-Iong } & \multicolumn{6}{|c|}{ Twice-over vs. idle } \\
\hline & & \multicolumn{3}{|c|}{2008} & \multicolumn{3}{|c|}{2009} & \multicolumn{3}{|c|}{2008} & \multicolumn{3}{|c|}{2009} \\
\hline & & $\beta$ & SE & $P$ & $\beta$ & SE & $P$ & $\beta$ & SE & $P$ & $\beta$ & SE & $P$ \\
\hline \multicolumn{14}{|l|}{ All birds } \\
\hline Richness & Gaussian & -0.14 & 0.30 & 0.64 & 0.53 & 0.34 & 0.13 & -1.60 & 0.56 & 0.01 & -0.03 & 0.52 & 0.95 \\
\hline Diversity & Gaussian & -0.09 & 0.08 & 0.27 & 0.08 & 0.07 & 0.20 & -0.25 & 0.15 & 0.10 & -0.04 & 0.10 & 0.66 \\
\hline \multicolumn{14}{|l|}{ Obligate grassland birds } \\
\hline Species richness & Gaussian & 0.32 & 0.18 & 0.09 & 0.50 & 0.23 & 0.03 & -1.99 & 0.34 & 0.00 & -1.89 & 0.35 & 0.00 \\
\hline Total abundance & Gaussian & 0.68 & 0.61 & 0.28 & 1.44 & 0.76 & 0.06 & -6.58 & 1.14 & 0.00 & -6.48 & 1.15 & 0.00 \\
\hline Species diversity & Gaussian & 0.11 & 0.05 & 0.03 & 0.16 & 0.08 & 0.04 & -0.53 & 0.09 & 0.00 & -0.59 & 0.12 & 0.00 \\
\hline Bobolink & Binomial & 0.74 & 0.31 & 0.02 & 0.65 & 0.36 & 0.08 & 0.65 & 0.56 & 0.25 & 0.89 & 0.50 & 0.08 \\
\hline Le Conte's sparrow & Binomial & -0.37 & 0.32 & 0.26 & -0.24 & 0.44 & 0.58 & -1.01 & 0.77 & 0.19 & -1.32 & 1.05 & 0.22 \\
\hline Savannah sparrow & Gaussian & 0.09 & 0.30 & 0.77 & -0.74 & 0.29 & 0.01 & -2.75 & 0.55 & 0.00 & -2.32 & 0.44 & 0.00 \\
\hline Sprague's pipit & Binomial & -0.16 & 0.27 & 0.55 & 0.00 & 0.28 & 0.99 & -21.71 & $N / A^{1}$ & 1.00 & -2.98 & 1.04 & 0.01 \\
\hline Vesper sparrow & Binomial & -0.01 & 0.31 & 0.97 & 0.34 & 0.30 & 0.25 & -0.45 & 0.65 & 0.49 & -0.26 & 0.50 & 0.61 \\
\hline Western meadowlark & Gaussian & -0.20 & 0.25 & 0.44 & 0.42 & 0.34 & 0.23 & -2.58 & 0.47 & 0.00 & -2.41 & 0.52 & 0.00 \\
\hline \multicolumn{14}{|c|}{ Facultative grassland birds } \\
\hline Species richness & Gaussian & -0.02 & 0.17 & 0.90 & 0.34 & 0.22 & 0.13 & -0.02 & 0.32 & 0.94 & 0.29 & 0.33 & 0.38 \\
\hline Total abundance & Gaussian & 0.13 & 0.69 & 0.85 & 0.61 & 0.83 & 0.47 & -0.32 & 1.28 & 0.80 & 1.10 & 1.27 & 0.39 \\
\hline Species diversity & Gaussian & 0.03 & 0.04 & 0.57 & 0.07 & 0.06 & 0.28 & -0.04 & 0.08 & 0.68 & 0.10 & 0.09 & 0.30 \\
\hline \multicolumn{14}{|l|}{ Brown-headed } \\
\hline cowbird & Binomial & 0.10 & 0.26 & 0.70 & -0.17 & 0.29 & 0.54 & -0.02 & 0.48 & 0.97 & 0.96 & 0.43 & 0.03 \\
\hline Clay-colored sparrow & Gaussian & -0.34 & 0.32 & 0.29 & -0.72 & 0.38 & 0.06 & -0.21 & 0.60 & 0.73 & 1.49 & 0.57 & 0.01 \\
\hline Eastern kingbird & Binomial & 0.18 & 0.26 & 0.49 & 0.03 & 0.29 & 0.91 & 0.09 & 0.48 & 0.85 & 0.65 & 0.42 & 0.13 \\
\hline Red-winged blackbird & Binomial & 0.05 & 0.26 & 0.86 & 0.04 & 0.27 & 0.89 & -0.51 & 0.47 & 0.28 & -0.06 & 0.42 & 0.88 \\
\hline \multicolumn{14}{|l|}{ Nongrassland birds } \\
\hline Species richness & Gaussian & -0.44 & 0.19 & 0.02 & -0.32 & 0.23 & 0.17 & 0.42 & 0.35 & 0.25 & 1.15 & 0.34 & 0.00 \\
\hline Total abundance & Gaussian & -3.12 & 2.92 & 0.29 & -1.39 & 0.50 & 0.01 & -1.34 & 5.42 & 0.81 & 2.48 & 0.76 & 0.00 \\
\hline Species diversity & Gaussian & -0.11 & 0.05 & 0.03 & 0.00 & 0.03 & 0.96 & 0.23 & 0.09 & 0.02 & 0.17 & 0.05 & 0.00 \\
\hline
\end{tabular}

${ }^{1}$ There were no occurrences of Sprague's pipit on idle sites in 2008.

pressures may be more beneficial for grassland birds than lighter grazing intensities (Pärt and Söderström 1999). As we found more grassland birds using season-long than twice-over sites, it seems unlikely that stocking rates for the season-long pastures in southwest Manitoba are high enough to be destructive; in contrast, higher stocking rates may contribute to the development of a heterogeneous vegetation structure across the pasture, producing numerous microhabitats suitable for a range of grassland bird species (e.g., Knopf 1996; Askins et al. 2007).

It is possible that season-long grazing benefited grassland birds because continuous season-long systems generate greater heterogeneity relative to rotational systems, which is consistent with the higher heterogeneity of vegetation vertical density we detected in season-long sites. Season-long grazing may create relatively temporally stable areas of high and low livestock use within the same pasture. Areas of high and low use are caused by cattle grazing behaviors, such as selective grazing and trampling, which results in nonuniform distribution of livestock on the landscape (Willms et al. 1990). Management practices, such as grazing systems, may indirectly influence grassland birds by altering the vegetation structure during the breeding season. Rotational grazing systems, which by definition change the vegetation cues used by grassland birds to select territories throughout a breeding season, may attract birds to sites that become unsuitable as the grazing regime changes.

Further, by limiting the movement of a herd to one paddock at a time, rotational grazing may reduce foraging selectivity (Coughenour 1991; Holechek et al. 1998), which may generate a more homogeneous vegetation structure within the paddock, consistent with our results. Although rotational grazing may not completely eliminate selective grazing by cattle (Stuth et al. 1987; Walker and Heitschmidt 1989), selectivity may be higher and occur at broader spatial scales in pastures that are grazed season-long. A heterogeneous environment generally increases species diversity of wildlife (Wiens 1997) and is required to maintain a diverse grassland bird community (Fuhlendorf and Engle 2001); this may explain why we detected lower species richness and diversity of grassland birds on twice-over compared with season-long pastures. 
Table 3. Effects of management on vegetation variables at the plot scale (litter depth, vegetation height, visual obstruction measurements [vertical density], and proportion cover of shrubs, forbs, grass, and exposed bare ground) in southwest Manitoba, Canada, in 2008 and 2009. Effects were modeled using generalized linear mixed-models. A negative value of $\beta$ indicates higher values on twice-over rotation sites, while a positive value of $\beta$ indicates higher abundances on season-long or idle sites. Significant responses are parameters with $P \leq 0.10$. The best-fitting probability distribution (Family) is shown for each variable.

\begin{tabular}{|c|c|c|c|c|c|c|c|c|c|c|c|c|c|}
\hline & \multirow[b]{3}{*}{ Family } & \multicolumn{6}{|c|}{ Twice-over vs. season-long } & \multicolumn{6}{|c|}{ Twice-over vs. idle } \\
\hline & & \multicolumn{3}{|c|}{2008} & \multicolumn{3}{|c|}{2009} & \multicolumn{3}{|c|}{2008} & \multicolumn{3}{|c|}{2009} \\
\hline & & $\beta$ & SE & $P$ & $\beta$ & SE & $P$ & $\beta$ & SE & $P$ & $\beta$ & SE & $P$ \\
\hline Litter depth & Gaussian & -0.23 & 0.24 & 0.36 & 0.05 & 0.14 & 0.71 & 0.71 & 0.45 & 0.13 & 0.61 & 0.21 & 0.01 \\
\hline Vegetation height & Gaussian & -3.06 & 3.39 & 0.37 & -0.22 & 0.74 & 0.77 & 14.33 & 6.30 & 0.03 & 4.80 & 1.12 & 0.00 \\
\hline Visual obstruction measurements & Gaussian & 0.03 & 0.06 & 0.67 & 0.13 & 0.09 & 0.18 & 0.47 & 0.12 & 0.00 & 1.01 & 0.14 & 0.00 \\
\hline Proportion cover of shrubs & Gaussian & 0.01 & 0.00 & 0.22 & 0.00 & 0.00 & 0.51 & 0.07 & 0.01 & 0.00 & 0.01 & 0.00 & 0.00 \\
\hline Proportion cover of forbs & Gaussian & 0.01 & 0.01 & 0.08 & 0.01 & 0.00 & 0.00 & 0.01 & 0.01 & 0.56 & 0.00 & 0.00 & 0.81 \\
\hline Proportion cover of grass & Gaussian & 0.12 & 0.03 & 0.00 & 0.13 & 0.03 & 0.00 & -0.01 & 0.06 & 0.90 & -0.03 & 0.05 & 0.59 \\
\hline Proportion cover of litter & Gaussian & 0.00 & 0.01 & 0.84 & -0.01 & 0.00 & 0.02 & -0.28 & 0.03 & 0.00 & -0.02 & 0.01 & 0.00 \\
\hline Proportion of exposed bare ground & Gaussian & 0.02 & 0.01 & 0.07 & 0.00 & 0.00 & 0.59 & 0.00 & 0.02 & 0.97 & 0.00 & 0.00 & 0.42 \\
\hline
\end{tabular}

Regardless of grazing system, grazing itself creates habitat more attractive to grassland birds than those ungrazed fields left idle (Frank and McNaughton 1993; Briske et al. 2008). For example, idle sites had a higher proportion of woody vegetation relative to grassland habitat than grazed sites, which was probably a consequence of the absence of disturbances such as livestock. The ecosystem in this region will succeed to shrub and trees in a short amount of time if left idled. The higher species overlap between season-long and twice-over sites reflects the similarities in habitat structure created by any type of grazing, regardless of grazing system. However, avian communities between the two grazing regimes still differed in some ways, showing approximately 20-25\% dissimilarity. Consistent with our observations regarding different effects of twice-over grazing on diversity of songbirds, and on individual songbirds, this suggests that differences in vegetation structure that we detected between season-long and twice-over pastures, although subtle, were ecologically significant.

Vegetation structure effects on birds in our study differed between obligate and facultative grassland birds, perhaps reflecting differences in habitat requirements. Many facultative grassland birds, such as clay-colored sparrows, brown-headed cowbirds (Molothrus ater), and eastern kingbirds (Tyrannus tyrannus), may be able to tolerate or even select for shrubbier sites (Knapton 1994; Debinski and Holt 2000), whereas most obligate grassland birds, such as chestnut-collared longspurs, Sprague's pipits, and Baird's sparrows, avoid them (Davis and Duncan 1999; Davis et al. 1999). The higher amount of exposed bare ground on season-long than twice-over sites in 2008 may also have attracted some obligate grassland birds, such as Savannah sparrows (our study and Davis 2004).
Grassland bird responses to vegetation structure were inconsistent between years. Interannual climatic differences in temperature and amount and timing of precipitation may have caused some differences in responses of grassland birds to grazing management. Interannual differences may also have resulted from changes in livestock grazing behaviours. Changes in habitat structure between years might directly influence habitat suitability for birds but may also influence the abundance of invertebrate prey available for insectivorous grassland birds (Milchunas et al. 1998; Söderström et al. 2001).

The species at risk observed in this study used grazed pastures and avoided idle fields but did not prefer one grazing regime over another; therefore, twice-over grazing seemed neither to harm nor benefit species at risk in southwest Manitoba. Sprague's pipits showed no preference between sites grazed season-long or twiceover rotationally. They tend to prefer sites with vegetation of medium height $(\leq 27.7 \mathrm{~cm})$ and density $(<8.0 \mathrm{~cm})$, few shrubs (<approximately $10 \%$ cover), and moderate litter depth (approximately $2.4 \mathrm{~cm}$; Sutter 1997; Madden et al. 2000). Since these vegetation characteristics did not differ significantly between grazing regimes, this may explain why Sprague's pipits occurred as frequently on pastures of each grazing treatment. Sprague's pipits tended to avoid idle fields in southwest Manitoba, likely due to the higher amount of treed areas and forest edges (Davis 2004; Koper and Schmiegelow 2006a). Although studies in Saskatchewan found Sprague's pipit densities were higher on ungrazed than grazed pastures (Dale 1984), the idle sites in Manitoba likely had more woody vegetation and tall grasses like big bluestem compared with drier sites further west in Saskatchewan.

We found little evidence that twice-over rotational grazing might contribute more to the conservation of grassland birds

Table 4. Sørensen's quantitative coefficients showing the similarity in bird species composition between each treatment pair in 2008 and 2009 , compared with expected maximum values $( \pm S D)$. Random samples from the same treatment are expected to have similarity coefficients equal to the expected maximum value, whereas dissimilar samples will have values less than the expected maximum value (Wolda 1981).

\begin{tabular}{lccccc}
\hline & \multicolumn{2}{c}{2008} & & & \\
\cline { 2 - 3 } \cline { 5 - 6 } Treatment & Expected maximum value & Quantitative coefficient & & Expected maximum value & Quantitative coefficient \\
\hline Twice-over and season-long & 0.85 & $0.64 \pm 0.36$ & 0.86 & $0.61 \pm 0.41$ \\
Twice-over and idle & 0.82 & $0.52 \pm 0.20$ & 0.86 & $0.45 \pm 0.27$ \\
Season-long and idle & 0.82 & $0.40 \pm 0.16$ & 0.86 & $0.40 \pm 0.16$ \\
\hline
\end{tabular}


relative to continuous season-long grazing, in our study area. While twice-over rotation sites supported more nongrassland birds than traditional grazing regimes, these species were generalists with relatively stable or increasing population trends (Pardieck and Sauer 2007), and as such are of low management concern. Although some previous studies have found that some grassland birds may avoid continuously grazed pastures and select rotationally grazed pastures (Temple et al. 1999), our results are consistent with most other studies, which detected no increase in bird nesting success or abundance among grazing systems (e.g., Ignatiuk and Duncan 2001; Koper and Schmiegelow 2006b). The similarities in avian community structure between grazing regimes suggests habitat quality is not improved by twice-over rotational grazing, which is consistent with other studies that detected neither habitat quality nor livestock production is improved by rotational grazing (Briske et al. 2008).

\section{MANAGEMENT IMPLICATIONS}

Our results suggest that it may be more beneficial to implement a number of grazing regimes throughout southwest Manitoba rather than only promoting and investing in twice-over rotational grazing, to create a diversity of grassland bird habitats across the ecoregion (Fuhlendorf and Engle 2001). We also found no evidence to suggest that twice-over grazing benefited songbird species at risk, although we also note that it was not detrimental. Although many rangeland practitioners and scientists value rotational grazing systems as an improved management regime, relatively few empirical studies actually support this (Manley et al. 1997; Briske et al. 2008). Our research suggests that existing traditional land management practices may actually promote conservation of grassland birds, rather than detract from it, and rotational grazing may not be a universal solution for grassland management in southwest Manitoba.

Other and perhaps greater threats to grassland bird habitats, where active management can certainly play a role, is in the control of woody and alien invasive species. Grazing alone can be a successful management regime to control some woody plant invasion if pastures are not in an advanced successional phase (Holechek et al. 1998). However, many of the idle fields sampled in this study are now sufficiently shrubby that alternative management methods, such as burning, must first be implemented before grazing alone could maintain open grassy areas. Our study demonstrates that control of invasive and woody species is critical for the conservation of prairies and grasslands in southwest Manitoba, and therefore active management is necessary for the conservation of these at-risk ecosystems.

\section{ACKNOWLEDGMENTS}

We acknowledge the support of the Manitoba Mixed-grass Prairie Habitat Stewardship Program and the Wildlife and Ecosystem Protection Branch of Manitoba Conservation, and the Manitoba Habitat Heritage Corporation. We thank P. L. Westhorpe for her support throughout the project. We thank Dr. S. G. Sealy, two anonymous reviewers, and the Associate Editor for providing comments on earlier drafts of this document. Help was provided during the field seasons from the West Souris River Conservation District office in Reston, Manitoba, and from C. Hullick, M. Denbow, P. Rakowski, S. M. Duran, E. Bokshowan, S. Carnochan, R. Gosselin, D. Potvin, L. Maskus, and J. Amyot.

\section{LITERATURE CITED}

Askins, R. A., F. Chávez-Ramírez, B. C. Dale, C. A. Haas, J. R. Herkert, F. L. Knopf, and P. D. VICKERY. 2007. Conservation of grassland birds in North America: understanding ecological processes in different regions. Report of the AOU Committee on Conservation. Washington, DC, USA: The American Ornithologists' Union. Ornithological Monographs No. 64. 46 p.

BiondinI, M. E., AND L. Manske. 1996. Grazing frequency and ecosystem processes in northern mixed prairie, USA. Ecological Applications 6:239-256.

BLoom, S. A. 1981. Similarity indices in community studies: potential pitfalls. Marine Ecology Progress Series 5:125-128.

Briske, D. D., J. D. Derner, J. R. Brown, S. D. Fulhendorg, W. R. Teague, R. L. Gilleen, A. J. Ash, AND W. D. Willms. 2008. Rotational grazing on rangelands: reconciliation of perception and experimental evidence. Rangeland Ecology \& Management 61:3-17.

Buckness, N. A., R. K. Murphy, K. F. Higgins, and J. Jenks. 2001. Breeding bird abundance and habitat on two livestock grazing regimes in North Dakota. Proceedings of the South Dakota Academy of Science 80:247-258.

Committee on the Status of Endangered Wildlife in Canada, Government of Canada. 2009. Committee on the Status of Endangered Wildlife in Canada: Canadian species at risk. Available at: http://www.cosewic.gc.ca. Accessed 21 April 2010.

Coughenour, M. B. 1991. Spatial components of plant-herbivore interactions in pastoral, ranching, and native ungulate ecosystems. Journal of Range Management 44:530-542.

DaLE, B. C. 1984. Birds of grazed and ungrazed grasslands in Saskatchewan. Blue Jay $42: 102-105$.

Daubenmire, R. 1959. A canopy-coverage method of vegetational analysis. Northwest Science 33:43-64.

Davis, S. K. 2004. Area sensitivity in grassland passerines: effects of patch size, patch shape, and vegetation structure on bird abundance and occurrence in southern Saskatchewan. Auk 121:1130-1145.

Davis, S. K., And D. C. Duncan. 1999. Grassland songbird occurrence in native and crested wheatgrass pastures of southern Saskatchewan. Studies in Avian Biology 19:211-218.

Davis, S. K., D. C. Duncan, and M. A. Skeel. 1999. Distribution and habitat associations of three endemic grassland songbirds in southern Saskatchewan. Wilson Bulletin 111:389-396.

Debinski, D. M., And R. D. Holt. 2000. A survey and overview of habitat fragmentation experiments. Conservation Biology 14:342-355.

Efford, M. G., AND D. K. Dawson. 2009. Effect of distance-related heterogeneity on population size estimates from point count. Auk 126:100-111.

Facelli, J. M., and S. T. A. Pickett. 1991. Plant litter: its dynamics and effects on plant community and structure. The Botanical Review 57:1-32.

Frank, D. A., and S. J. McNaughton. 1993. Evidence for the promotion of aboveground grassland production by native large herbivores in Yellowstone National Park. Oecologia 96:157-161.

Funlendorf, S. D., AND D. M. Engle. 2001. Restoring heterogeneity on rangelands: ecosystem management based on evolutionary grazing patterns. BioScience 51:625-632.

Hart, R. H., J. Bissio, M. J. Samuel, and J. W. Waggoner, JR. 1993. Grazing systems, pasture size, and cattle grazing behavior, distribution and gains. Journal of Range Management 46:81-87.

Heady, H. F. 1961. Continuous vs. specialized grazing systems: a review and application to the California annual type. Journal of Range Management 14:182-193.

Heitschmidt, R. K., S. L. Dowhower, AND J. W. Walker. 1987. Some effects of a rotational grazing treatment on quantity and quality of available forage and amount of ground litter. Journal of Range Management 40:318-321.

HERKERT, J. R. 1994. The effects of habitat fragmentation on Midwestern grassland bird communities. Ecological Applications 4:461-471.

Holechek, J. L., R. D. Pieper, And C. H. Herbel. 1998. Range management: principles and practices. 3rd ed. Upper Saddle River, NJ, USA: Prentice Hall. 542 p.

Ignatiuk, J. B., AND D. C. Duncan. 2001. Nest success of ducks on rotational and season-long grazing systems in Saskatchewan. Wildlife Society Bulletin 29:211-217. 
Johnson, D. H. 2008. In defense of indices: the case of bird surveys. Journal of Wildlife Management 72:857-868.

Johnson, D. H., AND L. D. IGL. 2001. Area requirements of grassland birds: a regional perspective. Auk 118:24-34.

KLIPPLE, G. E., AND R. E. Bement. 1961. Light grazing: is it economically feasible as a range-improvement practice? Journal of Range Management 14:57-62.

Knapton, R. W. 1994. Clay-colored sparrow (Spizella pallida). In: A. Poole and F. Gill [EDS.]. The birds of North America, No. 120. Philadephia, PA, USA: The Academy of Natural Sciences, and Washington, DC, USA: The American Ornithologists' Union. p. 1-16.

Knopf, F. L. 1994. Avian assemblages on altered grasslands. Studies in Avian Biology 15:247-257.

Knopf, F. L. 1996. Prairie legacies—birds. In: F. B. Samson and F. L. Knopf [eds.]. Prairie conservation: preserving North America's most endangered ecosystems. Washington, DC, USA: Island Press. p. 135-148.

Knopf, F. L., and F. B. Samson. 1997. Conservation of grassland vertebrates. In: F. L. Knopf and F. B. Samson [EDS.]. Ecology of Great Plains vertebrates and their habitats. New York, NY, USA: Springer-Verlag. p. 273-289.

Koper, N., And F. K. A. Schmiegelow. 2006a. A multi-scale analysis of avian response to habitat amount and fragmentation in the Canadian dry mixed-grass prairie. Landscape Ecology 21:1045-1059.

Koper, N., and F. K. A. Schmiegelow. 2006b. Effects of habitat management for ducks on target and nontarget species. Journal of Wildlife Management 70:823-834.

KreBS, C. J. 1999. Ecological methodology. 2nd ed. New York, NY, USA: Addison Wesley Longman. $620 \mathrm{p}$.

Madden, E. M., R. K. Murphy, A. J. Hansen, and L. Murray. 2000. Models for guiding management of prairie bird habitat in northwestern North Dakota. American Midland Naturalist 144:377-392.

Manley, W. A., R. H. Hart, M. J. Samuel, M. A. Smith, J. W. Waggoner, JR., and J. T. Manley. 1997. Vegetation, cattle, and economic responses to grazing strategies and pressures. Journal of Range Management 50:638-646.

McNaughton, S. J. 1979. Grazing as an optimization process: grass-ungulate relationships in the Serengeti. American Naturalist 113:691-703.

Messmer, T. A. 1990. Influence of grazing treatments on non-game birds and vegetation structure in south central North Dakota [dissertation]. Fargo, ND, USA: North Dakota State University. $164 \mathrm{p}$.

[MHHC] Manitoba Habitat Heritage Corporation. 2002. An introduction to the twice-over grazing system for native pastures. Winnipeg, MB, Canada: The Manitoba Habitat Heritage Corporation. 8 p.

Milchunas, D. G., W. K. Lauenroth, And I. C. BuRke. 1998. Livestock grazing: animal and plant biodiversity of shortgrass steppe and the relationship to ecosystem function. Oikos 83:65-74.

Milchunas, D. G., O. E. Sala, and W. K. Lauenroth. 1988. A generalized model of the effects of grazing large herbivores on grassland community structure. The American Naturalist 132:87-106.

Newton, I. 1998. Bird conservation problems resulting from agricultural intensification in Europe. In: J. M. Marzluff and R. Sallabanks [EDs.]. Avian conservation: research and management. Washington, DC, USA: Island Press. p. 307-322.

Onsager, J. A. 2000. Suppression of grasshoppers in the Great Plains through grazing management. Journal of Range Management 53:592-602.

Pardieck, K. L., and J. R. Sauer. 2007. The 1999-2003 Summary of the North American breeding bird survey. Bird Populations 8:28-45.

Pärt, T., And B. Söderström. 1999. The effects of management regimes and location in landscape on the conservation of farmland birds breeding in seminatural pastures. Biological Conservation 90:113-123.

Peterjohn, B. G., and J. R. Sauer. 1993. Population status of North American grassland birds from the North American Breeding Bird Survey, 1966-1996. In: P. D. Vickery and J. R. Herkert [EDS.]. Ecology and Conservation of
Grassland Birds in the Western Hemisphere. Studies in Avian Biology No. 19. Proceeding of a Conference. Association of Field Ornithologists. Cooper Onithological Society. October 1995; Tulsa, Oklahoma, USA. Los Angeles, CA, USA: Cooper Ornithological Society. p. 27-44.

Ranelluccl, C. L. 2010. Effects of twice-over rotation grazing on the relative abundances of grassland birds in the mixed-grass prairie region of southwestern Manitoba [thesis]. Winnipeg, MB, Canada: Natural Resources Institute, University of Manitoba. $154 \mathrm{p}$.

Reynolds, R. T., J. M. Scott, and R. A. Nussbaum. 1980. A variable circular-plot method for estimating bird numbers. Condor 82:309-313.

Roвbins, C. S. 1981. Effect of time of day on bird activity. Studies in Avian Biology 6:275-286.

Robel, R. J., J. N. Briggs, A. D. Dayton, and L. C. Hulbert. 1970. Relationships between visual obstruction measurements and weight of grassland vegetation. Journal of Range Management 23:295-297.

Samson, F. B., and F. L. Knopf. 1994. Prairie conservation in North America. BioScience 44:418-421.

Samson, F. B., F. L. Knopf, and W. R. Ostlie. 2004. Great Plains ecosystems: past, present, and future. Wildlife Society Bulletin 32:6-15.

SAvory, A. 1988. Holistic resource management. Covelo, CA, USA: Island Press. $545 \mathrm{p}$.

Shepherd, A., And S. M. McGinn. 2003. Climate change on the Canadian prairies from downscaled GCM data. Atmosphere-Ocean 41:301-316.

Söderström, B., T. Pärt, and E. Linnarsson. 2001. Grazing effects on between-year variation of farmland bird communities. Ecological Applications 11: $1141-1150$.

Stuth, J. W., P. S. Grose, and L. R. Roath. 1987. Grazing dynamics of cattle stocked at heavy rates in a continuous and rotational grazed system. Applied Animal Behaviour Science 19:1-9.

SutTeR, G. C. 1997. Nest-site selection and nest-entrance orientation in Sprague's Pipit. Wilson Bulletin 109:462-469.

Taylor, B. L., and T. Gerrodette. 1993. The use of statistical power in conservation biology: the vaquita and northern spotted owl. Conservation Biology 7:489-500.

Temple, S. A., B. M. Fevold, L. K. Paine, D. J. Undersander, and D. W. Sample. 1999. Nesting birds and grazing cattle: accommodating both on Midwestern pastures. Studies in Avian Biology 19:196-202.

Vickery, P. D., P. L. Tubaro, J. M. Cardosa da Silva, B. G. Peterjohn, J. R. Herkert, and R. B. Cavalcanti. 1999. Conservation of grassland birds in the Western hemisphere. Studies in Avian Biology 19:2-26.

Walker, J. W., and R. K. Heitschmidt. 1989. Some effects of a rotational grazing treatment on cattle grazing behavior. Journal of Range Management 42:337-342.

WiENs, J. A. 1969. An approach to the study of ecological relationships among grassland birds. Ornithological Monographs 8:1-93.

WIENS, J. A. 1992. The ecology of bird communities: foundations and patterns. Volume 1. Cambridge, UK: Cambridge University Press. 553 p.

WIENS, J. A. 1997. The emerging role of patchiness in conservation biology. In: S. T. A. Pickett, R. S. Ostfeld, M. Shachak, and G. E. Likens [eds.]. The ecological basis for conservation: heterogeneity, ecosystems, and biodiversity. New York, NY, USA: Chapman and Hall. p. 93-107.

Wiens, J. A., and J. T. Rotenberry. 1981. Habitat associations and community structure in shrubsteppe environments. Ecological Monographs 51:21-41.

Willms, W. D., S. Smoliak, and J. F. Dormaar. 1990. Vegetation response to timecontrolled grazing on mixed and fescue prairie. Journal of Range Management 43:513-517.

WILson, S. D., AND J. W. Belcher. 1989. Plant and bird communities of native prairie and introduced Eurasian vegetation in Manitoba, Canada. Conservation Biology 3:39-44.

WoldA, H. 1981. Similarity indices, sample size, and diversity. Oecologia 50:296-302. 